\title{
Effects of finishing diet and pre-slaughter fasting time on meat quality in crossbred pigs
}

\author{
Kirsi Partanen, Hilkka Siljander-Rasi \\ MTT Agrifood Research Finland, Animal Production Research, Tervamäentie 179, FI-05840 Hyvinkää, \\ Finland, email: kirsi.partanen@mtt.fi \\ Markku Honkavaara \\ Finnish Meat Research Institute, PO Box 56, FI-13101 Hämeenlinna, Finland \\ Marita Ruusunen \\ University of Helsinki, Department of Food Technology, PO Box 66, \\ FI-00014 Helsinki University, Finland
}

\begin{abstract}
The effects of the carbohydrate composition of finishing diet (fed from 80 to $107 \mathrm{~kg}$ of body weight) and the length of pre-slaughter fasting on pork quality were studied in a $2 \times 2$ factorial experiment with 80 crossbred pigs. The control finishing diet was based on barley and soybean meal, and the fibrous finishing diet was based on barley, barley fibre, faba beans, and rapeseed cake. These diets contained 465 and $362 \mathrm{~g}$ starch and 177 and $250 \mathrm{~g}$ dietary fibre per kg, respectively. The fasting times of 25 and $41 \mathrm{~h}$ were obtained by giving the pigs their last meal at different times. Longer fasting lowered the glycolytic potential of the longissimus lumborum muscle $(\mathrm{P}=0.01)$, whereas the finishing diet had no effect. Different muscles responded differently to the treatments. Longer fasting increased the ultimate $\mathrm{pH}$ of the semimembranosus muscle $(\mathrm{P}=$ 0.02), but did not affect that of the longissimus lumborum and semispinalis capitis muscles. The finishing diets did not affect the ultimate $\mathrm{pH}$ of the investigated muscles. A diet $\times$ fasting time interaction was seen in the lightness of the semimembranosus muscle $(\mathrm{P}=0.05)$. The fibrous diet resulted in darker meat than the control diet did in pigs that were fasted for $25 \mathrm{~h}(\mathrm{P}<0.05)$. Longer fasting darkened the meat colour in pigs fed the fibrous diet $(\mathrm{P}<0.05)$ but not in those fed the control diet. The meat from the semispinalis capitis muscle was darker in pigs fed the fibrous than those fed the control diet $(\mathrm{P}=0.04)$. The treatments did not affect the colour of the longissimus lumborum muscle. Longer fasting decreased drip loss from the meat of pigs fed the control diet $(\mathrm{P}<0.05)$. The eating quality of the pork was not influenced by the finishing diets or the fasting time. The pigs also grew equally fast on both finishing diets. In conclusion, a moderate alteration in the carbohydrate composition of a finishing diet or longer pre-slaughter fasting can have some effects on pork quality in crossbred pigs, but these effects vary in different muscles.
\end{abstract}

Key-words: Pigs, feeding, fasting, meat quality, glycolytic potential

(C) Agricultural and Food Science

Manuscript received May 2007 
Partanen, K. et al. Effects of finishing diet and fasting on pork quality

\section{Introduction}

Colour and water-holding capacity are important attributes of pork quality. Both these quality traits are affected by biochemical processes during the post-slaughter conversion of muscle to meat, where $\mathrm{pH}$ is an important factor. The extent of post-mortem $\mathrm{pH}$ fall and the ultimate $\mathrm{pH}$ of pork measured $24 \mathrm{~h}$ post mortem are mainly determined by the muscle glycogen content at slaughter (Bendall and Swatland 1988). High muscle glycogen levels result in pork with low ultimate $\mathrm{pH}$, pale colour, and decreased water-holding capacity (Miller et al. 2000, Hamilton et al. 2003). Muscle glycogen stores at slaughter are generally expressed as glycolytic potential. This is a measure of the compounds present in muscles that can be converted to lactic acid and thus contribute to the post-mortem $\mathrm{pH}$ decline (Monin and Sellier 1985). The glycolytic potential of muscles can be influenced by several factors like genotype (Monin and Sellier 1985, Enfält et al. 1997), feeding (Rosenvold et al. 2001a, Ruusunen et al. 2007), rearing conditions (Enfält et al. 1997), fasting (Bertol et al. 2005), and pre-slaughter handling practices (Hambrecht et al. 2004).

Dietary manipulation of muscle glycogen deposition has focused primarily on replacing starchrich cereals in finishing diets mainly with fat-rich protein feedstuffs and to a lesser extent with feedstuffs rich in fibre (Rosenvold et al. 2001a,b, 2002). Generally, these strategic, low-starch finishing diets have contained no cereals and considerably more protein than standard finishing diets that meet the amino acid requirements of finishing pigs. This is not desirable because the feeding of high-protein diets to finishing pigs increases urinary nitrogen excretion and ammonia emission from the slurry (Portejoie et al. 2004). It should therefore be investigated whether it is possible to manipulate muscle glycogen deposition by means of a partial replacement of cereals with fibre-rich feedstuffs while simultaneously using only moderate amounts of protein feedstuffs. In this context, faba beans seem an interesting feedstuff because they contain more protein and fibre but less starch than cereals (Bach Knudsen 1997). In addition, a smaller proportion of legume starch than cereal starch is digested and absorbed as glucose in the small intestine (Wiseman 2006). In our previous studies, increasing amounts of faba beans in diets based on barley and rapeseed meal have also darkened the colour of the longissimus dorsi muscle without having any negative effects on the eating quality of pork (Partanen et al. 2003).

A feed withdrawal of 16-24 h prior to slaughter is recommended in practice (Eikelenboom et al. 1991) in order to reduce the volume of stomach content and the risk of microbial contamination. Longer fasting has also been shown to decrease muscle glycolytic potential, increase ultimate $\mathrm{pH}$, darken meat colour, and decrease the risk of PSE (pale, soft, and exudative) meat (Jones et al. 1985, Eikelenboom et al. 1991, Guàrdia et al. 2004). However, fasting that is too long can increase the incidence of DFD (dark, firm, and dry) meat (Eikelenboom et al. 1991, Guàrdia et al. 2005). The magnitude of the fasting effect on meat quality can also depend on other factors like feeding and pre-slaughter handling practices (Leheska et al. 2003, Faucitano et al., 2006). However, the combined effects of dietary carbohydrate composition and pre-slaughter fasting time have scarcely been investigated.

The aim of this study was to investigate the effect of changing the carbohydrate composition of finishing diets by replacing soybean meal and part of the barley with faba beans, barley fibre, and rapeseed cake and the effect of the length of preslaughter fasting on the growth performance and carcass and meat quality of crossbred pigs.

\section{Material and methods}

\section{Animals, diets, and feeding}

Forty gilts and 40 barrows were used, of which 46 were F1 crosses of Finnish Landrace and Finnish Yorkshire, and 34 were back-crosses of these breeds. At a body weight of $23-28 \mathrm{~kg}$, pairs of gilts or barrows were formed and housed in pens of $0.95 \mathrm{~m} \times$ 
Vol. 16 (2007): 245-258

$2.83 \mathrm{~m}$ with a concrete floor in the lying area and a metal grate on the dunging alley. Wood shavings were used as bedding material.

The arrangements of the experimental treatments was $2 \times 2$ factorial, and the investigated factors were finishing diet (control vs. fibrous) and pre-slaughter fasting time (short vs. long). There were 10 pens (10 gilts and 10 barrows) in each treatment. A three-phase feeding regime was used. During the 35-day growing and 21-day earlyfinishing periods, all the pigs were fed diets based on barley and soybean meal. During the finishing period (from day 56 to slaughter), the pigs were fed either a control diet based on barley and soybean meal or a fibrous diet, which contained barley, barley fibre from a starch-ethanol production, faba beans, and cold-pressed rapeseed cake as the major ingredients. The diets fed during the growing, early-finishing, and finishing periods were formulated to meet or exceed the nutrient requirements of pigs from 25 to 55 , from 55 to 80 , and from 80 to 110 $\mathrm{kg}$ of body weight, respectively (MTT 2004). The ingredients and calculated nutrient compositions of the experimental diets are presented in Table 1. Dietary net energy content was calculated from the ingredients according to Schiemann et al. (1972) by using tabulated values for nutrient contents and their digestibility coefficients (MTT 2004). In the control and fibrous finishing diets, fat provided 4 and $14 \%$ and carbohydrates 82 and $73 \%$ of net energy, respectively, while the remaining $14 \%$ of net energy came from protein. The experimental diets were pelleted.

The pigs were fed according to a restricted feeding scale, in which the daily allowance was increased gradually from 13.0 to $29.8 \mathrm{MJ}$ NE per day. The daily ration was divided into two portions, which were given at 7 am and $3 \mathrm{pm}$. Water was available ad libitum. The pigs were weighed at the beginning of the growing, early-finishing, and finishing periods and then weekly until the mean body weight of pigs housed in the same pen reached $96 \mathrm{~kg}$ and the pigs were scheduled for slaughter during the following week. The final weight was measured before loading the pigs for transportation. The different fasting times were obtained by giving one half of the pigs their last meal at 7 am on the delivery day, and another half at $3 \mathrm{pm}$ on the previous day. The experimental protocol was evaluated and approved by the Animal Care Committee of MTT Agrifood Research Finland (Permit SIK10/04, 18.11.2004).

\section{Slaughtering and carcass quality evaluation}

The pigs were collected from the fattening unit between 10 am and $2 \mathrm{pm}$ and transported in a lorry ca $130 \mathrm{~km}$ to a commercial slaughter house. The pigs were kept overnight in the barn of the slaughterhouse, where no feed was given, but water was available. The pigs were slaughtered the following morning between 6.30 and $10 \mathrm{am}$. The time between the last meal and stunning averaged $25 \pm 0.9$ and 41 $\pm 0.8 \mathrm{~h}$ in the short and long fasting, respectively.

The pigs were stunned in groups of three pigs by $88 \%$ carbon dioxide for $3 \min 25 \mathrm{~s}$, exsanguinated, scalded with steam, cleaned, and eviscerated on a slaughter line that handled 133 pigs h$^{-1}$. Carcass lean meat content was measured on the warm carcasses ca 35 min after stunning with a Hennessy Grading probe GP4 (Hennessy Grading Systems, Auckland, New Zealand). The first fat depth measurement (S1) was taken at the last rib, 8 $\mathrm{cm}$ from the mid line, and the second fat depth (S2) and loin depth (LD) measurements between the $12^{\text {th }}$ and $13^{\text {th }}$ rib, $6 \mathrm{~cm}$ from the mid line. Carcass lean percentage was calculated as $56.713-(0.271 \times$ S1 $)-(0.620 \times$ S2 $)+(0.258 \times$ LD $)$. Simultaneously with the fat and lean depth measurements, the GP4 probe measured meat colour. Carcasses with average colour values $<58$ were classified as normal meat, with values $58-73$ as suspected PSE meat, and with values $\geq 74$ as PSE meat.

\section{Glycolytic potential}

Twenty four hours after the slaughter, a 2-g sample was taken from the longissimus lumborum muscle of one randomly selected pig per pen (from 20 pigs in 


\section{Partanen, K. et al. Effects of finishing diet and fasting on pork quality}

Table 1. Ingredients, calculated nutritive value, and analysed composition of the experimental diets.

\begin{tabular}{|c|c|c|c|c|}
\hline & & Early- & Fin & g diet \\
\hline & Growing diet & & Control & Fibrous \\
\hline Ingredients, $\%$ & & & & \\
\hline Barley & 78.95 & 81.81 & 87.56 & 57.86 \\
\hline Barley fibre & - & - & - & 12.00 \\
\hline Faba beans & - & - & - & 15.00 \\
\hline Soybean meal & 17.86 & 15.34 & 9.81 & - \\
\hline Rapeseed cake, cold-pressed & - & - & - & 12.77 \\
\hline Mineral and vitamin premix ${ }^{a}$ & 1.30 & 1.30 & 1.30 & 1.30 \\
\hline Calcium carbonate & 0.83 & 0.76 & 0.71 & 0.63 \\
\hline Monocalcium phosphate & 0.66 & 0.49 & 0.37 & 0.28 \\
\hline L-Lysine $\mathrm{HCl}$ & 0.26 & 0.22 & 0.20 & 0.12 \\
\hline DL-Methionine & 0.05 & 0.02 & - & 0.03 \\
\hline L-Threonine & 0.08 & 0.06 & 0.04 & 0.01 \\
\hline Calculated nutritive value & & & & \\
\hline Net energy, $\mathrm{MJ} \mathrm{kg}^{-1}$ & 8.65 & 8.74 & 8.74 & 8.74 \\
\hline Net energy distribution, $\%$ & & & & \\
\hline Protein & 17 & 16 & 14 & 14 \\
\hline Fat & 5 & 5 & 4 & 13 \\
\hline Carbohydrates & 78 & 79 & 82 & 73 \\
\hline Apparent ileal digestible amin & & & & \\
\hline Lysine & 8.8 & 8.0 & 6.6 & 6.6 \\
\hline Methionine+cystine & 5.2 & 4.7 & 4.0 & 3.9 \\
\hline Threonine & 5.3 & 4.8 & 3.9 & 3.9 \\
\hline Calcium, $\mathrm{g} \mathrm{kg}^{-1}$ & 7.5 & 7.0 & 6.4 & 6.4 \\
\hline Digestible phosphorus, $\mathrm{g} \mathrm{kg}^{-1}$ & 3.0 & 2.6 & 2.4 & 2.4 \\
\hline Analysed nutrient contents & & & & \\
\hline Dry matter, $\mathrm{g} \mathrm{kg}^{-1}$ & 880 & 878 & 879 & 892 \\
\hline Ash, $\mathrm{g} \mathrm{kg}^{-1}$ & 53 & 50 & 46 & 49 \\
\hline Crude protein, $\mathrm{g} \mathrm{kg}^{-1}$ & 182 & 166 & 144 & 155 \\
\hline Crude fat, $\mathrm{g} \mathrm{kg}^{-1}$ & 22 & 18 & 15 & 40 \\
\hline Sugars, $\mathrm{g} \mathrm{kg}^{-1}$ & 38 & 34 & 31 & 36 \\
\hline Starch, $\mathrm{g} \mathrm{kg}^{-1}$ & 409 & 435 & 465 & 361 \\
\hline Total dietary fibre ${ }^{\mathrm{b}}, \mathrm{g} \mathrm{kg}^{-1}$ & 176 & 175 & 177 & 250 \\
\hline Neutral detergent fibre, $\mathrm{g} \mathrm{kg}^{-1}$ & 164 & 163 & 161 & 229 \\
\hline Acid detergent fibre, $\mathrm{g} \mathrm{kg}^{-1}$ & 55 & 54 & 52 & 93 \\
\hline Lignin, $\mathrm{g} \mathrm{kg}^{-1}$ & 9 & 11 & 7 & 16 \\
\hline Hemicellulose, $\mathrm{g} \mathrm{kg}^{-1}$ & 108 & 109 & 109 & 137 \\
\hline Cellulose, $\mathrm{g} \mathrm{kg}^{-1}$ & 47 & 44 & 46 & 77 \\
\hline
\end{tabular}

aPer kilogram of feed, the premix contained Ca, 2.3 g; P, 0.8 g; Mg, 0.5 g; NaCl, 3.3 g, Fe, 103 mg; Cu, 22 mg; Zn, 91 mg; Mn, 23 mg; Se, $0.28 \mathrm{mg}$; I, $0.28 \mathrm{mg}$; vitamin A, $5170 \mathrm{IU}$; vitamin $\mathrm{D}_{3}$, $517 \mathrm{IU}$; vitamin E, $50 \mathrm{mg}$; thiamin, $2 \mathrm{mg}$; riboflavin, $5 \mathrm{mg}$; pyridoxine, $3 \mathrm{mg}$; vitamin $\mathrm{B}_{12} 20 \mu \mathrm{g}$; biotin, $0.2 \mathrm{mg}$; pantothenic acid, $14 \mathrm{mg}$; niacin, $20 \mathrm{mg}$; folic acid, $2 \mathrm{mg}$; and vitamin $\mathrm{K}, 2 \mathrm{mg}$.

${ }^{\mathrm{b}}$ Total dietary fibre $=$ dry matter - ash - crude protein - ether extract - sugars - starch. 
Vol. 16 (2007): 245-258

total), frozen in liquid nitrogen, and stored at $-80^{\circ} \mathrm{C}$ until analysed for glycogen and lactate contents. Glycogen content was analysed as glucose: $10 \mu 1$ of homogenate ( $1 \mathrm{~g}$ of muscle sample in $10 \mathrm{ml}$ of ice-cold phosphate buffer ( $\mathrm{pH}$ 7.0)) were hydrolysed in $200 \mu \mathrm{l}$ of $0.1 \mathrm{M} \mathrm{HCl}$ at $100^{\circ} \mathrm{C}$ for $2 \mathrm{~h}$, after which the $\mathrm{pH}$ was adjusted to 6.5-7.5 (Lowry and Passoneau 1973), and glucose was determined via $\mathrm{NADP}^{+}$reduction with a linked assay involving hexokinase and glucose-6-phosphate dehydrogenase (Glucose (HK) 16-50, Sigma Diagnostics). Lactate concentration was determined from the homogenate via $\mathrm{NAD}^{+}$reduction with a linked assay involving lactate dehydrogenase and glutamate pyruvate transaminase (Boehringer-Mannheim no. 139 084). The glycolytic potential ( $\mu$ mol lactate $\mathrm{g}^{-1}$ ) was calculated according to Monin and Sellier (1985) as follows: $2 \times$ (glycogen + glucose + glucose-6phosphate) + lactate.

\section{Meat quality measurements}

The ultimate $\mathrm{pH}$ and meat colour were measured $24 \mathrm{~h}$ post mortem in the three muscles longissimus lumborum, semimembranosus, and semispinalis capitis from the left side of the carcass. The ultimate pH was measured with a Knick Portamess 752 pH meter and a Mettler Toledo Inlab 427 electrode. Colour measurements $\left(L^{*}=\right.$ lightness, $a^{*}=$ redness, and $b^{*}=$ yellowness) were taken with a Minolta DP301 device (Minolta Camera Co., Ltd., Japan) from a freshly cut surface. Drip loss was determined from the longissimus lumborum muscle by weighing a 100-g sample of meat before and after storage in a sealed plastic bag at $4^{\circ} \mathrm{C}$ for three days. The weight difference was the drip, and it was expressed as a percentage. Intramuscular fat content of the longissimus lumborum muscle between the $4^{\text {th }}$ and $5^{\text {th }}$ lumbar vertebra was determined as crude fat content using a modified Soxhlet extractor (Soxtec 1047 Hydrolysing Unit and Soxtec Avanti Extraction, Foss Tecator).

The eating quality of the pork was evaluated by a trained 4-member panel from the Finnish Meat Research Institute (3-4 days post mortem) using samples taken from the longissimus lumborum muscle between the $1^{\text {st }}$ and $4^{\text {th }}$ lumbar vertebra. A total of 44 samples of longissimus lumborum were sliced into $1.5-\mathrm{cm}$ steaks, grilled until they reached an internal temperature of $68^{\circ} \mathrm{C}$ (Palux Rotimat), and served as hot as possible to the panellists. Four samples were served during one evaluation (one from each finishing diet and fasting time combination). Panellists rated each stake for tenderness, juiciness, and taste by using a 7 -point scale $(7=$ extremely tender, juicy, or good flavour, and $1=$ extremely tough, dry, or bad off-flavour). Overall acceptability was calculated as the sum of the evaluated traits.

\section{Feed analyses}

Feed dry matter content was determined by drying at $103^{\circ} \mathrm{C}$ for $16 \mathrm{~h}$. The ash, crude protein, and crude fat contents were determined according to the AOAC (1990) methods 942.05, 968.06, and 962.09 , respectively. Sugar content was determined according to Somogyin (1945), and starch content according to McCleary et al. (1994) using assay format 2 without pullulanase/ $\beta$-amylase treatment. Total dietary fibre content was calculated as the following difference: dry matter - ash - crude protein - ether extract - sugars - starch. The neutral and acid detergent fibre (NDF and ADF) contents were determined according to van Soest et al. (1991) and Robertson and van Soest (1981), respectively, and the hemicellulose and cellulose contents were calculated as the differences NDF - ADF and ADF - lignin, respectively.

\section{Statistical analyses}

The data were analysed using the MIXED procedure of SAS (SAS ${ }^{\circ}$ Systems for Windows, release 8.02). The growth performance data were analysed with pen as the experimental unit, and the carcass and meat quality data with pig as the experimental unit. The model applied to the data included the fixed 
Partanen, K. et al. Effects of finishing diet and fasting on pork quality

effects of finishing diet, fasting time, and their interaction and the random effect of block (blocks were based on breed and sex). Meat quality traits (ultimate $\mathrm{pH}$ and colour) measured in different muscles were analysed as repeated measurements using an unstructured covariance structure. Because of significant interactions between the muscle and finishing diet and/or fasting time in meat colour measurements, the data were also analysed separately for each muscle. Categorical data were analysed with the chi ${ }^{2}$ test.

\section{Results}

\section{Diet composition}

The analysed composition of the experimental diets is presented in Table 1. The dietary crude protein contents were close to the targeted values. The fibrous finishing diet contained $104 \mathrm{~g} \mathrm{~kg}^{-1}$ less starch, $73 \mathrm{~g} \mathrm{~kg}^{-1}$ more total dietary fibre, and 68 and $41 \mathrm{~g} \mathrm{~kg}^{-1}$ more NDF and ADF, respectively, than the control diet.

\section{Production performance and carcass quality}

Before the finishing period, the pigs grew $1024 \mathrm{~g}$ $\mathrm{d}^{-1}$ and used $2.28 \mathrm{~kg}$ of feed per $\mathrm{kg}$ of gain. Neither the finishing diets nor the pre-slaughter fasting time had any significant effects on the growth performance of the pigs during the finishing period or total fattening (Table 2).

A total of 14 pigs from seven pens had been slaughtered by mistake immediately after being delivered to the slaughter house and from six of them no carcasses were received for meat quality measurements. These pigs had ca $17 \mathrm{~h}$ less fasting time than the other pigs, and they were excluded from the carcass and meat quality data. The investigated treatments did not have any significant effects on carcass weight, carcass yield, or the leanness of carcasses. However, the fibrous finishing diet in- creased the colour values $(\mathrm{P}<0.05)$, which were assessed by a Hennessy GP4 probe and indicated the presence of PSE carcasses.

\section{Glycolytic potential and quality of fresh pork}

The fibrous finishing diet tended to lower $(\mathrm{P}=0.08)$ the residual muscle glycogen content (30.2 vs. 24.7 $\mu$ mol lactate $\mathrm{g}^{-1}$ ), but it did not affect the lactate content or glycolytic potential measured in the longissimus lumborum muscle (Table 3). Longer pre-slaughter fasting lowered both the residual glycogen content (31.7 vs. $23.2 \mu$ mol lactate $\mathrm{g}^{-1}, \mathrm{P}=0.01$ ) and glycolytic potential (159.1 vs. $137.8 \mu \mathrm{mol}$ lactate $\mathrm{g}^{-1}, \mathrm{P}=0.01$ ) of the muscle.

There were distinct differences in the frequency of ultimate $\mathrm{pH}$ and $L^{*}$ values in the longissimus lumborum, semimembranosus, and semispinalis capitis muscles (Figures 1 and 2). The ultimate $\mathrm{pH}$ values from 5.7 to 5.9 were considered as optimal. Suboptimal ultimate $\mathrm{pH}$ values $(\mathrm{pH}<5.7)$ were noticeably more frequent in the longissimus lumborum (84\%) and semimembranosus $(72 \%)$ muscles than in the semispinalis capitis (26\%) muscle. Elevated ultimate $\mathrm{pH}$ values $(\geq 6.0)$ were seen mainly in the semispinalis capitis muscle. According to Barton-Gade (1981), carcasses can be considered DFD when the ultimate $\mathrm{pH}$ of the semispinalis capitis is $\geq 6.5$ or the ultimate $\mathrm{pH}$ of both the longissimus dorsi and semispinalis capitis is $>6.1$. Carcasses are considered slightly DFD when the ultimate $\mathrm{pH}$ value of the longissimus dorsi is $\leq 6.1$ and that of the semispinalis capitis is $>6.1$ but not more than 6.5. Based on these criteria, only one pig had DFD meat, and it had been fed the fibrous diet and fasted for $41 \mathrm{~h}$. The proportions of slightly DFD carcasses were 11.1 and $12.5 \%$ in the pigs fed the control diet and fasted for 25 and $41 \mathrm{~h}$, respectively, and 6.3 and $18.8 \%$ in the pigs fed the fibrous diet and fasted for 25 and $41 \mathrm{~h}$, respectively. Differences between the treatments were not significant. The colour of the longissimus lumborum was optimal $(L * 40-54)$ in $80 \%$ of the carcasses, while pale meat was seen more often in the semispinalis capitis and semimembranosus muscles. In the latter 
Vol. 16 (2007): 245-258

Table 2. Effects of finishing diet and pre-slaughter fasting length on growth performance and carcass quality of fattening pigs.

\begin{tabular}{|c|c|c|c|c|c|c|c|c|}
\hline \multirow{2}{*}{$\begin{array}{l}\text { Finishing diet } \\
\text { Fasting time }\end{array}$} & \multicolumn{2}{|c|}{ Control } & \multicolumn{2}{|c|}{ Fibrous } & \multirow[b]{2}{*}{ SEM } & \multicolumn{3}{|c|}{ Probability } \\
\hline & $25 \mathrm{~h}$ & $41 \mathrm{~h}$ & $25 \mathrm{~h}$ & $41 \mathrm{~h}$ & & Diet & Fasting & $\begin{array}{l}\text { Diet } \times \\
\text { fasting }\end{array}$ \\
\hline No. of pens & 10 & 10 & 10 & 10 & & & & \\
\hline \multicolumn{9}{|l|}{ Body weight, $\mathrm{kg}$} \\
\hline Initial & 26.1 & 26.0 & 25.7 & 24.6 & 0.7 & 0.18 & 0.33 & 0.14 \\
\hline Start of early-finishing & 80.6 & 79.8 & 79.5 & 79.5 & 1.2 & 0.50 & 0.70 & 0.73 \\
\hline Final & 105.7 & 105.1 & 106.8 & 106.1 & 1.1 & 0.24 & 0.45 & 0.91 \\
\hline Days on finishing diet & 25.9 & 26.2 & 28.0 & 27.5 & 1.8 & 0.13 & 0.96 & 0.72 \\
\hline \multicolumn{9}{|l|}{ Body weight gain, $\mathrm{g} \mathrm{d}^{-1}$} \\
\hline Growing+early-finishing* & 1025 & 1017 & 1017 & 1039 & 24 & 0.67 & 0.69 & 0.37 \\
\hline Finishing & 980 & 958 & 986 & 971 & 38 & 0.76 & 0.55 & 0.91 \\
\hline Overall & 1008 & 1000 & 1007 & 1018 & 25 & 0.54 & 0.92 & 0.46 \\
\hline \multicolumn{9}{|l|}{$\mathrm{Kg}$ feed per $\mathrm{kg}$ gain } \\
\hline Growing+early-finishing* & 2.28 & 2.28 & 2.29 & 2.25 & 0.04 & 0.88 & 0.54 & 0.52 \\
\hline Finishing & $3.21^{\mathrm{a}}$ & $3.47^{\mathrm{b}}$ & $3.17^{\mathrm{a}}$ & $3.29^{\mathrm{ab}}$ & 0.09 & 0.23 & 0.04 & 0.44 \\
\hline Overall & 2.57 & 2.63 & 2.58 & 2.58 & 0.05 & 0.52 & 0.38 & 0.35 \\
\hline No. of carcasses & 18 & 16 & 16 & 16 & & & & \\
\hline Carcass weight, $\mathrm{kg}$ & 77.1 & 76.5 & 77.6 & 76.3 & 1.1 & 0.88 & 0.34 & 0.65 \\
\hline Carcass yield, \% & 73.1 & 73.2 & 73.0 & 72.3 & 0.4 & 0.15 & 0.38 & 0.19 \\
\hline \multicolumn{9}{|l|}{ Hennessy GP } \\
\hline Last rib fat depth, mm & 10.9 & 11.7 & 11.7 & 10.8 & 0.7 & 0.96 & 0.97 & 0.09 \\
\hline Fat depth betw. $12^{\text {th }} \& 13^{\text {th }}$ rib, $\mathrm{mm}$ & 10.8 & 10.9 & 12.1 & 10.9 & 0.9 & 0.23 & 0.29 & 0.20 \\
\hline Loin depth, mm & 53.5 & 52.8 & 51.4 & 51.4 & 1.7 & 0.18 & 0.76 & 0.77 \\
\hline Lean percentage & 60.8 & 60.2 & 59.3 & 60.1 & 0.9 & 0.11 & 0.89 & 0.14 \\
\hline Colour value & $43.3^{\mathrm{ab}}$ & $41.6^{\mathrm{a}}$ & $47.8^{\mathrm{ab}}$ & $49.5^{\mathrm{b}}$ & 3.0 & 0.01 & 0.99 & 0.50 \\
\hline
\end{tabular}

two muscles, $L^{*}$ values were within the optimal range only in 40 and $23 \%$ of carcasses, respectively.

There was a diet $\times$ fasting time interaction $(\mathrm{P}=$ $0.05)$ in the average ultimate $\mathrm{pH}$ of the investigated three muscles (Table 3). The combination of fibrous finishing diet and $41 \mathrm{~h}$ fasting resulted in a higher ultimate $\mathrm{pH}$ than the other three treatments $(\mathrm{P}<$ $0.05)$. The effects of the finishing diets and the fasting time on meat colour $\left(L^{*}, a^{*}, b^{*}\right)$ were not significant. However, there were significant interactions between the muscle, finishing diet, and fasting time in the lightness $\left(L^{*}\right)$ and yellowness $\left(b^{*}\right)$ of pork, indicating that different muscles responded differently to the investigated treatments. Therefore, the data were analysed separately for each muscle as well. The finishing diet and pre-slaughter fasting time did not have any significant effects on the ultimate $\mathrm{pH}$ or colour of the longissimus lumborum muscle. Longer fasting decreased drip loss in pigs fed the control diet $(\mathrm{P}=$ $0.05)$. Fasting increased the ultimate $\mathrm{pH}$ of the semimembranosus muscle ( 5.59 vs. $5.67 ; \mathrm{P}=0.02)$. There was a diet $\times$ fasting time interaction in the lightness of the semimembranosus muscle $(\mathrm{P}=0.05)$. In pigs fed the fibrous finishing diet, the meat was lighter in pigs fasted for 41 instead of $25 \mathrm{~h}(\mathrm{P}<0.05)$, while the difference observed after the different fasting times 
Partanen, K. et al. Effects of finishing diet and fasting on pork quality
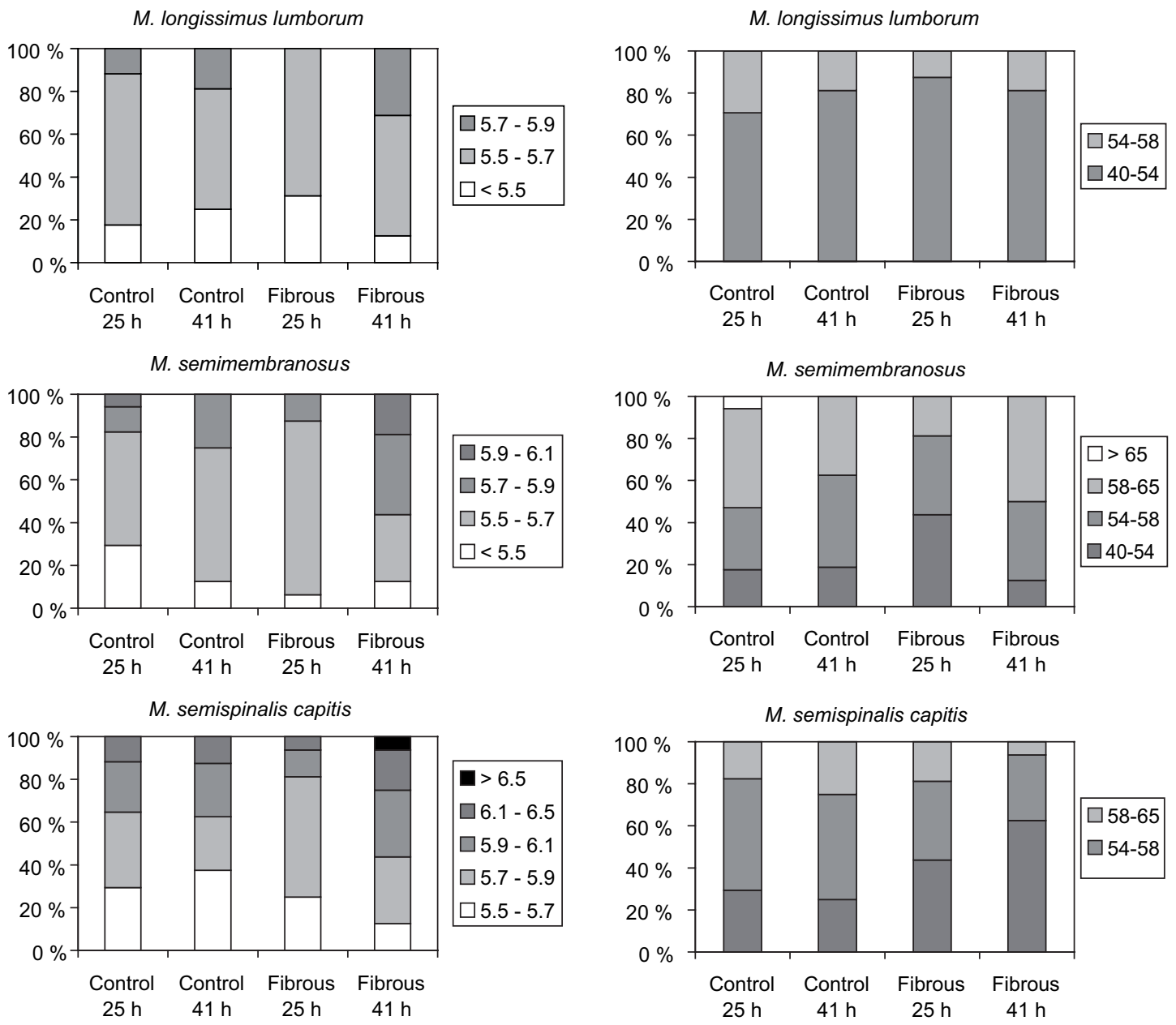

Figure 1. Effects of finishing diet (control vs. fibrous) and pre-slaughter fasting time $(25 \mathrm{vs} .41 \mathrm{~h}$ ) on the frequencies of ultimate $\mathrm{pH}$ values in the longissimus lumborum, semimembranosus, and semispinalis capitis muscles.

was not significant in pigs fed the control diet. In pigs fasted for $25 \mathrm{~h}$, the fibrous diet resulted in darker meat than the control diet $(\mathrm{P}<0.05)$. The ultimate $\mathrm{pH}$ of the semispinalis capitis muscle was not affected by the investigated treatments, but the control finishing diet resulted in lighter (56.0 vs. 54.2; $\mathrm{P}=0.04)$ and more yellowish meat colour ( 6.3 vs. $5.3 ; \mathrm{P}=0.02)$ than the fibrous finishing diet did.

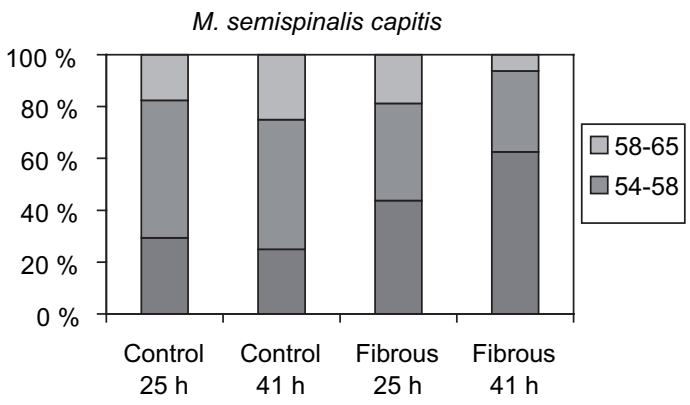

Figure 2. Effects of finishing diet (control vs. fibrous) and pre-slaughter fasting time ( $25 \mathrm{vs} .41 \mathrm{~h}$ ) on the frequency of lightness $\left(L^{*}\right)$ values in the longissimus lumborum, semimembranosus, and semispinalis capitis muscles.

\section{Intramuscular fat and pork eating quality}

Neither the finishing diets nor pre-slaughter fasting had any significant effects on the intramuscular fat content or eating quality (taste, juiciness, and tenderness) of pork as determined in the longissimus lumborum muscle (Table 4). 
Vol. 16 (2007): 245-258

Table 3. Effects of finishing diet and pre-slaughter fasting time on glycolytic potential of the longissimus lumborum muscle and on the quality traits of pork in the longissimus lumborum, semimembranosus, and semispinalis capitis muscles.

\begin{tabular}{|c|c|c|c|c|c|c|c|c|}
\hline \multirow{2}{*}{$\begin{array}{l}\text { Finishing diet } \\
\text { Fasting time }\end{array}$} & \multicolumn{2}{|c|}{ Control diet } & \multicolumn{2}{|c|}{ Fibrous diet } & \multirow[b]{2}{*}{ SEM } & \multicolumn{3}{|c|}{ Probability } \\
\hline & $25 \mathrm{~h}$ & $41 \mathrm{~h}$ & $25 \mathrm{~h}$ & $41 \mathrm{~h}$ & & Diet & Fasting & $\begin{array}{l}\text { Diet } \times \\
\text { fasting }\end{array}$ \\
\hline No. of samples & 9 & 9 & 9 & 8 & & & & \\
\hline Glycogen, $\mu \mathrm{mol} \mathrm{g}{ }^{-1}$ & $35.9^{\mathrm{b}}$ & $24.5^{\mathrm{a}}$ & $27.5^{\mathrm{ab}}$ & $21.8^{\mathrm{a}}$ & 3.2 & 0.08 & 0.01 & 0.36 \\
\hline Lactic acid, $\mu$ mol lactate $\mathrm{g}^{-1}$ & 94.8 & 93.6 & 96.6 & 89.4 & 2.5 & 0.62 & 0.09 & 0.21 \\
\hline Glycolytic potential, $\mu \mathrm{mol}$ lactate $\mathrm{g}^{-1}$ & $166.6^{\mathrm{b}}$ & $142.6^{\mathrm{ab}}$ & $151.6^{\mathrm{ab}}$ & $133.0^{\mathrm{a}}$ & 8.5 & 0.14 & 0.01 & 0.74 \\
\hline No. of samples per muscle & 17 & 16 & 16 & 16 & & & & \\
\hline \multicolumn{9}{|l|}{ Average in three muscles } \\
\hline Ultimate $\mathrm{pH}$ & $5.66^{\mathrm{a}}$ & $5.68^{a}$ & $5.65^{\mathrm{a}}$ & $5.78^{\mathrm{b}}$ & 0.03 & 0.11 & 0.01 & 0.05 \\
\hline$L^{*}$ & 54.8 & 54.5 & 53.7 & 53.6 & 0.6 & 0.07 & 0.68 & 0.77 \\
\hline$a^{*}$ & 7.3 & 7.0 & 7.3 & 7.2 & 0.4 & 0.77 & 0.52 & 0.71 \\
\hline$b^{*}$ & 4.5 & 4.5 & 4.2 & 4.3 & 0.2 & 0.26 & 0.92 & 0.74 \\
\hline \multicolumn{9}{|l|}{ Longissimus lumborum } \\
\hline Ultimate $\mathrm{pH}$ & 5.57 & 5.57 & 5.54 & 5.62 & 0.03 & 0.68 & 0.16 & 0.13 \\
\hline$L^{*}$ & 51.0 & 50.1 & 51.1 & 50.3 & 0.1 & 0.89 & 0.24 & 0.95 \\
\hline$a^{*}$ & 5.8 & 5.9 & 6.4 & 6.3 & 0.4 & 0.12 & 0.67 & 0.81 \\
\hline$b^{*}$ & 2.8 & 3.0 & 3.6 & 3.0 & 0.3 & 0.18 & 0.54 & 0.18 \\
\hline Drip loss, $\%$ & $4.3^{\mathrm{b}}$ & $3.1^{\mathrm{a}}$ & $3.8^{\mathrm{ab}}$ & $3.7^{\mathrm{ab}}$ & 0.3 & 0.93 & 0.05 & 0.09 \\
\hline \multicolumn{9}{|l|}{ Semimembranosus } \\
\hline Ultimate $\mathrm{pH}$ & $5.59^{\mathrm{a}}$ & $5.63^{\mathrm{ab}}$ & $5.60^{\mathrm{a}}$ & $5.71^{\mathrm{b}}$ & 0.03 & 0.17 & 0.02 & 0.29 \\
\hline$L^{*}$ & $57.7^{\mathrm{b}}$ & $56.8^{\mathrm{ab}}$ & $54.7^{\mathrm{a}}$ & $57.5^{\mathrm{b}}$ & 0.9 & 0.21 & 0.28 & 0.05 \\
\hline$a^{*}$ & 5.4 & 4.8 & 5.7 & 5.4 & 0.3 & 0.25 & 0.17 & 0.68 \\
\hline$b^{*}$ & 4.4 & 4.0 & 3.7 & 4.4 & 0.3 & 0.75 & 0.58 & 0.08 \\
\hline \multicolumn{9}{|l|}{ Semispinalis capitis } \\
\hline Ultimate $\mathrm{pH}$ & 5.82 & 5.84 & 5.81 & 5.99 & 0.06 & 0.27 & 0.08 & 0.16 \\
\hline$L^{*}$ & $55.8^{\mathrm{ab}}$ & $56.3^{\mathrm{b}}$ & $55.0^{\mathrm{ab}}$ & $53.4^{\mathrm{a}}$ & 0.9 & 0.04 & 0.52 & 0.24 \\
\hline$a^{*}$ & 10.5 & 10.0 & 9.8 & 9.7 & 0.6 & 0.41 & 0.64 & 0.65 \\
\hline$b^{*}$ & $6.3^{\mathrm{b}}$ & $6.2^{\mathrm{ab}}$ & $5.2^{\mathrm{a}}$ & $5.5^{\mathrm{ab}}$ & 0.4 & 0.02 & 0.75 & 0.60 \\
\hline
\end{tabular}

Table 4. Effects of finishing diet and pre-slaughter fasting time on the intramuscular fat content and eating quality of pork in the longissimus lumborum muscle.

\begin{tabular}{|c|c|c|c|c|c|c|c|c|}
\hline \multirow{2}{*}{$\begin{array}{l}\text { Finishing diet } \\
\text { Fasting time }\end{array}$} & \multicolumn{2}{|c|}{ Control diet } & \multicolumn{2}{|c|}{ Fibrous diet } & \multirow[b]{2}{*}{ SEM } & \multicolumn{3}{|c|}{ Probability } \\
\hline & $25 \mathrm{~h}$ & $41 \mathrm{~h}$ & $25 \mathrm{~h}$ & $41 \mathrm{~h}$ & & Diet & Fasting & $\begin{array}{l}\text { Diet } \times \\
\text { fasting }\end{array}$ \\
\hline No. of samples & 6 & 4 & 5 & 5 & & & & \\
\hline Intramuscular fat, $\%$ & 1.4 & 1.4 & 1.8 & 1.9 & 0.3 & 0.24 & 0.92 & 0.90 \\
\hline Tenderness & 4.7 & 4.4 & 4.7 & 4.7 & 0.3 & 0.72 & 0.56 & 0.64 \\
\hline Juiciness & 4.8 & 4.6 & 4.9 & 4.8 & 0.2 & 0.56 & 0.52 & 0.97 \\
\hline Taste & 4.9 & 4.9 & 4.9 & 4.9 & 0.1 & 0.82 & 0.94 & 0.33 \\
\hline Acceptability $^{\mathrm{a}}$ & 14.5 & 13.8 & 14.5 & 14.4 & 0.6 & 0.64 & 0.56 & 0.63 \\
\hline
\end{tabular}


Partanen, K. et al. Effects of finishing diet and fasting on pork quality

\section{Discussion}

Diets for finishing pigs generally contain from ca 85 to over $90 \%$ cereals or maize. Starch is the major energy-yielding constituent in both of these crops and can represent $47-69 \%$ of dry matter (Bach Knudsen 1997). Consequently, the starch content of finishing diets ranges from 400 to $550 \mathrm{~g} \mathrm{~kg}^{-1}$. In this study, the replacement of one third of barley and all soybean meal with faba beans, barley fibre, and coldpressed rapeseed cake lowered the starch content of the finishing diets from 465 to $361 \mathrm{~g} \mathrm{~kg}^{-1}$. Pure starch consists predominantly of $\alpha$-glucan in the form of amylose and amylopectin, which can be present in various proportions in starch granules. Legumes contain 30-40\% amylose and 60-70\% amylopectin in starch, while cereals contain $25-30 \%$ amylose and $70-75 \%$ amylopectin. Raw starches high in amylopectin are digested more quickly than those high in amylose (Thorne et al. 1983). According to Wiseman (2006), most cereal starch is digested and absorbed as glucose in the small intestine of pigs, while some legume starch escapes ileal enzymatic digestion and is subjected to microbial fermentation in the large intestine. Therefore, it is relevant to assume that the replacement of barley with faba beans did not only limit the starch intake but also altered the site and extent of starch digestion in pigs fed the fibrous finishing diet. Legume proteins and antinutritive factors may also reduce the availability of starch for digestion (Thorne et al. 1983). The total dietary fibre, hemicellulose, and cellulose contents were naturally greater in the fibrous than in the control finishing diet.

The control and fibrous finishing diets were formulated to provide equal amounts of net energy and apparent ileal digestible amino acids per $\mathrm{kg}$. Therefore the choice of finishing diet was not expected to and did not affect the growth performance or carcass lean percentage of the pigs. Similarly, Rosenvold et al. (2001a) reported no significant effects on body weight gain or feed conversion ratio when finishing pigs were fed muscle-glycogenreducing diets containing rapeseed cake, sugar beet pulp, and/or grass meal as the major ingredients. However, the INURA diet (main ingredients: rape- seed cake and inulin) has improved body weight gain compared to a standard finishing diet (Rosenvold et al. 2001a, 2002). In the study of Rosenvold et al. (2001b), several low-starch but high-fibre and high-protein diets resulted in reduced feed intake and growth performance of finishing pigs.

The two fasting times, 25 and $41 \mathrm{~h}$ from the last meal to slaughter, were obtained by altering the length of on-farm fasting while treating the pigs in a similar manner during loading, transportation, and lairage. The 16-h difference in on-farm fasting had no effect on carcass weight or carcass yield. This is contrary to findings in several earlier studies in which longer fasting has been reported to reduce gut fill and viscera weight and consequently increase carcass yield (Leheska et al. 2003, Bidner et al. 2004). Generally, carcass yield has increased when fasting time has exceeded $20 \mathrm{~h}$, and both fasting times in this study were longer.

Based on the colour measurements taken in the slaughter line with a Hennessy GP4, none of the carcasses had clearly PSE meat (colour values $\geq 74$ ). The average colour values were higher in carcasses of pigs fed the fibrous instead of the control finishing diet $(\mathrm{P}=0.01)$, but fasting time did not affect colour values. According to Guàrdia et al. (2004), the minimum risk of PSE condition is achieved when on-farm fasting time is between 18 and 22 h. Similarly, Eikelenboom et al. (1991) recommended an on-farm fasting period of 16-24 $h$ to reduce the incidence of PSE meat.

The glycolytic potential is an estimate of the glycogen content present in the muscle at slaughter (Monin and Sellier 1985). It is generally determined from samples taken after exsanguination. However, when pigs are slaughtered in a commercial slaughter house, like in this study, the sampling of carcasses can be difficult due to high slaughter speed. According to Maribo et al. (1999), the glycolytic potential on the longissimus dorsi muscle was similar when determined 4 or $30 \mathrm{~h}$ after slaughter. Therefore, the glycolytic potential was determined from muscle samples taken one day after the slaughter.

The glycolytic potential of the longissimus lumborum muscle ranged from 97 to $196 \mu$ mol lactate $\mathrm{g}^{-1}$. The fibrous finishing diet did not manage to 
Vol. 16 (2007): 245-258

lower the muscle glycolytic potential. It is likely that the change in the carbohydrate composition of the finishing diet was not sufficiently large to significantly affect the muscle glycolytic potential. Rosenvold et al. (2001b) fed slaughter pigs different diets with low starch but high fibre, fat, and protein contents, which managed to lower the muscle glycogen content during the three-week finishing period.

When pigs are fasted before slaughter, they use muscle glycogen stores to get energy. Pre-slaughter fasting has been shown to deplete muscle glycogen reserves in pigs, but the magnitude of the effect seems to depend on various factors like the length of fasting, transportation, and lairage conditions (Leheska et al. 2003). In this study, fasting decreased both the residual glycogen content and the glycolytic potential of the longissimus lumborum, which is in accordance with the results of Leheska et al. (2003) and Bertol et al. (2005).

In this study, finishing diet did not affect the average ultimate $\mathrm{pH}$ of the investigated three muscles but the ultimate $\mathrm{pH}$ was increased by longer fasting. The combination of fibrous finishing diet and $41 \mathrm{~h}$ fasting resulted in the highest ultimate $\mathrm{pH}$ values. In individual muscles, increasing fasting time from 25 to $41 \mathrm{~h}$ increased the ultimate $\mathrm{pH}$ of the semimembranosus muscle and tended to increase that of the semispinalis capitis muscle, while the longissimus lumborum remained unaffected. Other studies have also shown that increased feed withdrawal decreases muscle glycolytic potential and consequently increases the ultimate $\mathrm{pH}$ and darkness of meat (Jones et al. 1985, Eikelenboom et al. 1991).

The rate at which the muscle $\mathrm{pH}$ and glycogen content decline during the conversion of muscle to meat has significant impact on the development of fresh meat quality attributes (Scheffler and Guarrard 2007). In this study, we were not able to measure these changes in the slaughterhouse. Normally, the $\mathrm{pH}$ declines gradually from 7.4 in living muscle to roughly 5.6-5.7 within 6-8 h post mortem, and the ultimate $\mathrm{pH}$ at $24 \mathrm{~h}$ is about 5.3-5.7. Some pigs exhibit rapid glycolysis which produces heat and slows carcass chilling. This results in rapid $\mathrm{pH}$ decline to less than 6.0 during the first hour after slaughter but the ultimate $\mathrm{pH}$ is ca 5.3-5.7. In contrast, extended $\mathrm{pH}$ decline proceeds at normal rate but continues to low ultimate $\mathrm{pH}$ of 5.3-5.5 (acid meat). The combination of high temperature at low $\mathrm{pH}$ or abnormally low ultimate $\mathrm{pH}$ results in paler colour and reduced water holding capacity. In the study of Eikelenboom et al. (1991), drip loss was decreased after $24 \mathrm{~h}$ of feed withdrawal before delivery, while $16 \mathrm{~h}$ of feed withdrawal did not affect drip loss. In this study, $41 \mathrm{~h}$ fasting reduced drip loss from meat in pigs that were the control diet.

Although the fibrous finishing diet did not affect the muscle glycolytic potential and ultimate $\mathrm{pH}$, it darkened the colour of the semispinalis capitis muscle, and it darkened the colour of the semimembranosus in pigs that were fasted for 25 h. In the study of Partanen et al. (2003), barleybased diets that contained faba beans and rapeseed cake darkened the colour of the longissimus dorsi muscle. Diets containing high amounts of rapeseed products have also been reported to result in darker and redder meat (Dransfield et al. 1985). Rosenvold et al. (2001b) found that a low starch diet with rapeseed cake and peas increased the ultimate $\mathrm{pH}$ of pork but did not affect its colour. Previously, Rosenvold et al. (2001a,b) had reported that decreased muscle glycogen content improves the water-holding capacity of different muscles. In this study, however, drip loss was not influenced by the finishing diets.

Prolonged fasting can result in increased incidence of DFD meat that has high ultimate $\mathrm{pH}(\geq$ 6.0) and poor microbiological stability (Eikelenboom et al. 1991, Guàrdia et al. 2005). In this study, the combination of the fibrous finishing diet and 41 $h$ of fasting resulted in DFD in one pig, while the share of slightly DFD pigs did not differ between the treatments.

The quality scoring of cooked meat samples did not show any significant differences in the tenderness, juiciness, and taste or the overall acceptability of cooked loin samples resulting from the different finishing diets or pre-slaughter fasting times. In addition, the number of scored meat samples per treatment was small. According to Støier et al. (2006), meat from pigs fed a strategic, low-carbohydrate finishing diet exhibited taste differences in cooked 


\title{
AGRICULTURAL AND FOOD SCIENCE
}

\author{
Partanen, K. et al. Effects of finishing diet and fasting on pork quality
}

meat patties that were made from minced shoulder clod and blade roll. The meat patties from pigs fed the control diet had more bitter/burnt flavours and those from pigs fed the strategic finishing feed had more sour flavours. In the study of Partanen et al. (2003), the eating quality of pork from pigs fed diets containing faba beans and rapeseed meal did not differ from that of pigs fed barley and soybean meal based diet.

\section{Conclusions}

Changing the carbohydrate composition of a finishing diet by replacing soybean meal and some barley with fibrous feed ingredients like faba beans, barley fibre, and cold-pressed rapeseed cake has little impact on the muscle glycolytic potential and the ultimate $\mathrm{pH}$ of fresh pork, but it can darken meat colour in some muscles. Increasing pre-slaughter fasting is a more effective means of manipulating muscle glycolytic potential, and it also increases the ultimate $\mathrm{pH}$ of fresh pork, but it has little impact on meat colour. Longer fasting can also reduce drip loss from meat in pigs that are fed a high-starch diet based on barley and soybean meal. Neither a fibrous finishing diet nor pre-slaughter fasting seem to affect the eating quality of pork. Furthermore, moderate changes in the carbohydrate composition of finishing diet do not affect the production performance of pigs.

Acknowledgements. This study was part of the project Quality of Finnish Pork, and it was funded by the Finnish Ministry of Agriculture and Forestry (Dnro 4982/502/2003) and the Finnish meat industry.

\section{References}

AOAC 1990. Official Methods of Analysis. Association of Official Analytical Chemists, Inc., Arlington, Virginia, USA. 1141 p.

Bach Knudsen, K.E. 1997. Carbohydrate and lignin contents of plant materials used in animal feeding. Animal
Feed Science and Technology 67: 319-338

Barton-Gade, P. 1981. The measurement of meat quality in pigs post mortem. In: Porcine Stress and Meat Quality - Causes and Possible Solutions to the Problems. Eds. T. Frøystein \& N. Standal, pp. 205-218. Agricultural and Food Research Society, Ås, Norway.

Bendall, J.R. \& Swatland, H.J. 1988. A review of the relationships of $\mathrm{pH}$ with physical aspects of pork quality. Meat Science 24: 85-126.

Bertol, T.M., Ellis, M., Ritter, M.J. \& McKeith, F.K. 2005. Effect of feed withdrawal and handling intensity on longissimus muscle glycolytic potential and blood measurements in slaughter weight pigs. Journal of Animal Science 83: 1536-1542.

Bidner, B.S., Ellis, M., Witte, D.P., Carr, S.N. \& McKeith, F.K. 2004. Influence of dietary lysine level, pre-slaughter fasting, and rendement napole genotype on fresh pork quality. Meat Science 68: 53-60.

Dransfield, E., Nute, G.R., Mottram, D.S., Rowan, T.G. \& Lawrence, T.L.J. 1985. Pork quality from pigs fed on low glucosinolate rapeseed meal: Influence of level in the diet, sex and ultimate $\mathrm{pH}$. Journal of the Science of Food and Agriculture 36: 546-556.

Eikelenboom, G., Hoving-Bolink, A. H. \& Sybesma, W. 1991. Effect of feed withdrawal before delivery on pork quality and carcass yield. Meat Science 29: 25-30.

Enfält, A.-C., Lundström, K., Hansson, I., Lundeheim, N. \& Nyström, P.E. 1997. Effects of outdoor rearing and sire breed (Duroc or Yorkshire) on carcass composition and sensory and technological meat quality. Meat Science 45: 1-15.

Faucitano, L. Saucier, L., Correa, J.A., Méthot, S., Giguère, A., Foury, A., Mormède, P. \& Bergeron, R. 2006. Effect of feed texture, meal frequency and pre-slaughter fasting on carcass and meat quality, and urinary cortisol in pigs. Meat Science 74: 697-703.

Guàrdia, M.D., Estany, J., Balash, S., Oliver, M.A., Gispert, M. \& Diestre, A. 2004. Risk assessment of PSE meat due to the pre-slaughter conditions and RYR1 gene in pigs. Meat Science 67: 471-478.

Guàrdia, M.D., Estany, J., Balash, S., Oliver, M.A., Gispert, M. \& Diestre, A. 2005. Risk assessment of DFD meat due to the pre-slaughter conditions in pigs. Meat Science 70: 709-716.

Hambrecht, E., Eissen, J.J., Noijen, R.I.J., Ducro, B.J., Smits, C.H.M., den Hartog, L.A. \& Verstegen, M.W.A. 2004. Preslaughter stress and muscle energy largely determine pork quality at two commercial processing plants. Journal of Animal Science 82: 1401-1409.

Hamilton, D.N., Miller, K.D., Elis, M., McKeith, F.K. \& Wilson, E.R. 2003. Relationships between longissimus glycolytic potential and swine growth performance, carcass traits, and pork quality. Journal of Animal Science 81: 2206-2212.

Jones, S.D., Rompala, R.E. \& Haworth, C.R. 1985. Effects of fasting and water restriction on carcass shrink and pork quality. Canadian Journal of Animal Science 65: 613-618.

Leheska, J.M., Wulf, D.M. \& Maddock, R.J. 2003. Effects of fasting and transportation on pork quality development and extent of post-mortem metabolism. Journal of Animal Science 81: 3194-3202.

Lowry, O.H. \& Passoneau, J.V. 1973. A flexible system of 


\title{
AGRICULTURAL AND FOOD SCIENCE
}

\author{
Vol. 16 (2007): 245-258
}

enzymatic analysis. Academic Press, New York.

Maribo, H., Støier, S \& Jørgensen, P.F. 1999. Procedure for determination of glycolytic potential in porcine $m$. longissimus dorsi. Meat Science 51: 191-193.

McCleary, B.V., Solah, V. \& Gibson, T.S. 1994. Quantitative measurement of total starch in cereal flours and products. Journal of Cereal Science 20: 51-58.

Miller, K.D., Ellis, M., Bidner, B. \& McKeith, F.K. 2000. Porcine longissimus glycolytic potential level effects on growth performance, carcass, and meat quality characteristics. Journal of Muscle Foods 11: 169-181.

Monin, G. \& Sellier, P. 1985. Pork of low technological quality with a normal rate of muscle $\mathrm{pH}$ fall in the intermediate post-mortem period: The case of the Hampshire breed. Meat Science 13: 49-63.

MTT 2004. Feed tables and feeding recommendations 2004: ruminants - pigs - poultry - fur animals - horses. MTT reports 86.84 p. (in Finnish). Available in Internet: http://www.mtt.fi/mtts/pdf/mtts86.pdf.

Partanen, K., Alaviuhkola, T., Siljander-Rasi, H. \& Suomi, K. 2003. Faba beans in diets for growing-finishing pigs. Agricultural and Food Science in Finland 12: 35-47.

Portejoie, S., Dournad, J.Y., Martinez, J. \& Lebreton, Y. 2004. Effect of lowering dietary crude protein on nitrogen excretion, manure composition and ammonia emission from fattening pigs. Livestock Production Science 91: 45-55.

Robertson, J.B. \& van Soest, P.J. 1981. The detergent system of analysis and its application to human foods. In: The Analysis of Dietary Fibre in Foods eds. W.P.T. James \& O. Theander; pp. 123-158. Marcel Dekker, New York

Rosenvold, K., Lærke, H.N., Jensen, S.K., Karlson, A.H., Lundström, K. \& Andersen, H.J. 2001a. Strategic finishing feeding as a tool on the control of pork quality. Meat Science, 59, 397-406.

Rosenvold, K., Lærke, H.N., Jensen, S.K., Karlson, A.H., Lundström, K. \& Andersen, H.J. 2002. Manipulation of critical quality indicators and attributes in pork through vitamin E supplementation, muscle glycogen reducing finishing feeding and pre-slaughter stress. Meat Science 62: 485-496.

Rosenvold, K., Petersen, J.S., Lærke, H.N., Jensen, S.K., Therkildsen, M., Karlsen, A.H., Møller, H.S. \& Andersen, H.J. 2001b. Muscle glycogen stores and meat quality as affected by strategic finishing feeding of slaughter pigs. Journal of Animal Science 79: 382-391.

Ruusunen, M., Partanen, K., Pösö, R. \& Puolanne, E. 2007. The effect of dietary protein supply on carcass composition, size off organs, muscle properties and meat quality of pigs. Livestock Science 107: 170-181.

Scheffler, T.L. \& Gerrard, D.E. 2007. Mechanisms controlling pork quality development: The biochemistry controlling post-mortem energy metabolism. Meat Science 77: 7-16

Schiemann, R., Nehring, K., Hoffmann, L., Jentsch, W. \& Chudy, A. 1972. Energetische Futterbewertung und Energienormen. VEB Deutscher Landwirtschaftsverlag, Berlin.

Somogyi, M. 1945. A new reagent for the determination of sugars. Journal of Biological Chemistry 160: 61-68.

Støier, S., Aaslyng, M.D., Lauridsen, L., Bredie, W.L.P. \& Jørgenssen, A.S. 2006. Interaction between pan temperature and end point temperature on the eating quality of pork with various raw meat qualities. In: $52^{\text {nd }} \mathrm{In}$ ternational Congress of Meat Science and Technology. pp. 577-578.

Thorne, M.J., Thompson, L.U. \& Jenkins, D.J.A. 1983. Factors affecting starch digestibility and the glycemic response with special reference to legumes. The American Journal of Clinical Nutrition 38: 481-488.

van Soest, P.J., Robertson, J.B. \& Lewis, B.A. 1991. Methods of dietary fiber, neutral detergent fiber, and nonstarch polysaccharides in relation to animal nutrition. Journal of Dairy Science 74: 3583-3597.

Wiseman, J. 2006. Variations in starch digestibility on nonstarch ruminants. Animal Feed Science and Technology 130: 66-77. 
Partanen, K. et al. Effects of finishing diet and fasting on pork quality

\section{SELOSTUS}

Kirsi Partanen, Hilkka Siljander-Rasi, Markku Honkavaara ja Marita Ruusunen

Maa- ja elintarviketalouden tutkimuskeskus, Lihateollisuuden tutkimuskeskus ja Helsingin yliopisto

Tutkimuksen tavoitteena oli selvittää $2 \times 2$ faktorikokeessa, miten loppukasvatusrehun hiilihydraattikoostumus ja teurastusta edeltävän paaston pituus vaikuttavat sianlihan laatuun. Lihasikojen kasvatuskokeessa 80 maatiais- ja yorkshirerotujen risteytyssikaa jaettiin pareittain, sukupuolet erikseen neljään koekäsittelyyn. Kontrollina olleessa ohra-soijarouhepohjaisessa loppukasvatusrehussa oli tärkkelystä $465 \mathrm{~g} / \mathrm{kg}$ ja kuitua 177 g/kg. Kuitupitoisessa, ohraa, ohrakuitua, härkäpapua ja kylmäpuristettua rypsiä sisältäneessä loppukasvatusrehussa oli tärkkelystä $361 \mathrm{~g} / \mathrm{kg}$ ja kuitua $250 \mathrm{~g} / \mathrm{kg}$. Loppukasvatusrehuja syötettiin 80 kilon elopainosta alkaen teurastukseen saakka eli noin neljä viikkoa. Teurastusta edeltäneet $25: \mathrm{n}$ ja 41 tunnin paastot saatiin aikaan muuttamalla viimeisen rehuannoksen antamisajankohtaa. Kuljetus ja odotusaika teurastamossa olivat kaikilla sioilla samanlaiset.

Siat kasvoivat kontrolliruokinnalla ja kuitupitoisella ruokinnalla yhtä nopeasti. Loppukasvatusrehu ja paaston pituus eivät vaikuttaneet ruhopainoon eivätkä lihaprosenttiin. Paaston pidentäminen pienensi ulkofileestä ( $M$. longissimus lumborum) mitattua lihaksen glykolyyttistä potentiaalia, mutta ruokinta ei vaikuttanut siihen. Vaikka ruokinta ja paasto eivät muuttaneet ulkofileen loppupH-arvoa (24 tuntia teurastuksesta) tai väriä, pidempi paasto vähensi kudosnesteiden valumaa kontrollirehua syöneiden sikojen lihasta. Loppukasvatuksen ruokinta ei vaikuttanut sisäpaistin (M. semimembranosus) loppupH-arvoon, mutta pidempi paasto nosti sitä. Sisäpaistin värissä oli ruokinnan ja paaston välillä yhdysvaikutus. Kuitupitoinen rehu tummensi sisäpaistin väriä 25 tuntia paastonneilla sioilla, ja pidempi paasto tummensi kuitupitoista rehua syöneiden sikojen sisäpaistin väriä. Vaikka ruokinta ei vaikuttanut niskapaistin (M. semispinalis capitis) loppu-pH-arvoon, kuitupitoinen rehu tummensi sen väriä. Sen sijaan paaston pituudella ei ollut vaikutusta niskapaistin pH-arvoon eikä väriin. Loppukasvatuksen ruokinta ja paaston pituus eivät myöskään vaikuttaneet ulkofileestä määritettyyn lihan syöntilaatuun. Tulosten perusteella maltillinen loppukasvatusrehun tärkkelyspitoisuuden alentaminen ja kuitupitoisuuden lisääminen ja pitempi teurastusta edeltävä paasto voivat jossain määrin vaikuttaa tuoreen sianlihan laatuun, mutta vaikutukset ovat erilaisia eri lihaksissa. 